\title{
Assessment of Biochemical and Antioxidant Enzymes and Stress Hormone in Crossbred-Cows during Peripartum Period
}

\author{
Anju Yadav ${ }^{1}$, M.M. Pathan ${ }^{1 *}$, S.P. Madhira ${ }^{1}$, A.M. Pande ${ }^{1}$ and R.J. Modi ${ }^{2}$ \\ ${ }^{1}$ Department of Veterinary Physiology \& Biochemistry, ${ }^{2}$ Department of Livestock Production \\ Management, College of Veterinary Sci. \& A. H., AAU, Anand, Gujarat, India \\ *Corresponding author
}

\section{A B S T R A C T}

Keywords

Antioxidant

enzymes,

Stress hormone,

Crossbred-cows

Article Info

Accepted:

12 June 2019

Available Online:

10 July 2019
The whole study was conducted on six adult pregnant Crossbred cows during Peripartum period. Nine $\mathrm{ml}$ of whole blood was collected and plasma was separated and stored in deep freeze at $-20^{\circ} \mathrm{C}$ until analyzed. Serum concentration of ALT (U/L) and AST (U/L) were significantly (P < 0.05) decreased on the day parturition. While ALP (IU/L) and ACP (IU/L) levels were significantly $(\mathrm{P}<0.05)$ increased on the day of parturition. Level of cortisol was significantly $(\mathrm{P}<0.05)$ higher on the day parturition than any other days during the peri-partum period. Antioxidant enzymes like SOD $(\mathrm{U} / \mathrm{ml})$, LPO (nmol) and GPx $(\mathrm{nmol} / \mathrm{min} / \mathrm{ml})$ were significantly $(\mathrm{P}<0.05)$ elevated on the day of parturition. The biochemical parameters and enzymes were influenced significantly $(\mathrm{P}<0.05)$ by the physiological changes occurring during the peri-partum period in the crossbred cows.

\section{Introduction}

The transition (or periparturient) period is the most critical period in dairy cows regarding health status and production. Lactation is the period of increased physiological stress, which is observed especially in early lactation. Rapid differentiation of secretory parenchyma, intense mammary gland growth, and the onset of copious milk synthesis and secretion in early lactation give rise to the high energy and oxygen requirements (Gitto et al., 2002), thus resulting in the generation of reactive oxygen species (ROS). Under normal physiological condition, the generated ROS are neutralized by the antioxidant system and the redox 
homeostasis is maintained in the body. In contrast, oxidative stress occurs when there is an imbalance between increased production of ROS and reduced capacity of the antioxidant system. Several studies showed that ROS production in the blood of dairy cows during the periparturient period can overwhelm certain antioxidant defence and result in increased oxidative stress (Sordillo et al., 2007). Immediately after calving, animals undergo severe negative energy balance, indicated by alterations in blood metabolites and hormone profiles (Wathes et al., 2009).

The hormonal pattern established during the latter portion of gestation triggers parturition. During the last three weeks of gestation, the fetus begins to release hormones from the adrenal cortex (predominantly cortisol) due to increased fetal stress and this stress hormone cortisol released from the fetus is responsible for production of other important hormones like, estrogen and PGF $2 \alpha$ from mother. A combination of hormones from the fetus, placenta and dam induce a series of events leading to parturition (Rhodes, 2003). Also this stress hormone influences the metabolic functions and feed intake by the animal after parturition (Ingvartsen and Andersen, 2000).

After parturition cow experiences a period of high energy demand for milk production and insufficient feed intake. However, just after calving the high yielding cows cannot increase Dry Matter Intake (DMI) as fast as the increased nutrient demands required for lactation (Roche et al., 2009; Hayirli et al., 2003; NRC, 2001). Therefore to deal with this nutrient shortage, the cow mobilises body reserve fat and protein. This situation causes the Negative Energy Balance (NEB) and increases fat mobilization (Rukkwamsuk et al., 2000) and resulted into cell structure damage and alteration in various important enzyme activity such as AST, ALT, GGT and ALP in the liver.
To know more about the stress experienced by the animals during the peripartum period particularly in crossbred cattle an investigation was planned at Department of Physiology and Biochemistry, College of Veterinary Science and A.H., Anand on Crossbred cows during their peripartum period.

\section{Materials and Methods}

The whole study was conducted on six adult pregnant, apparently healthy, Crossbred cows during Peripartum period i.e. from 45 days before parturition to 45 days after parturition. The research was approved by the Institutional animal Ethics Committee (IAEC.No.235/VBC/2016). The experimental animals were reared in semi-open housing system which is made up of concrete floor under asbestos roofed housing system constructed east west direction and well covered with trees. These experimental cows were not separated from other cows. The experimental animals were maintained on ICAR feeding standard (1998).

Nine $\mathrm{ml}$ of whole blood from each experimental animal was collected from jugular vein in heparinized vaccutainer. The blood was collected from 45 days before parturition at weekly interval i.e. -45day,38day,-31day, -24day, -17day, -10day,-3 day, on the day of parturition and upto 45 days after parturion i.e. on +3 day, +7 day, +10 day, +15 day,+30day and +45day in accordance with the probable date of parturition. Plasma from the blood samples was separated by centrifugation at 3000rpm for 15 minutes and stored in deep freeze at $-20{ }^{\circ} \mathrm{C}$ until analyzed for enzymes like acid phosphatase, alkaline phosphatase, aspartate transaminase and alanine transaminase, hormone like cortisol along with antioxidant enzymes like glutathione peroxidase, superoxide dismutase and melondialdehyde (Lipid Hydroperoxidase). 
These plasma biochemical estimation were carried out in the Department of Veterinary Physiology and Biochemistry, College of Veterinary Science and Animal Husbandry, Anand Agricultural University, Anand using Diagnostic kits manufactured by Crest Biosystems, Coral Clinical Systems, Goa, by Spectrophotometer (model Visiscan 167). Blood Plasma cortisol was estimated by ELISA method using Bovine Cortisol (CORT) ELISA kit (Cat.No: MBS028594, manufactured in Sandiego, USA). Estimation of Glutathione peroxidase (GPx), Superoxide Dismutase and Lipid Hydroperoxide (LPO) were performed by assay Kits manufactured by Cayman Chemicals, USA. The data obtained in the present study was statistically analyzed by the Completely Randomised Design (CRD). Statistical analysis performed at Department of Agriculture Statistics, B. A. College of Agriculture, Anand Agricultural University, Anand.

The statistical model for CRD with one observation per unit

$Y i j=\mu+t i+e i j$

$\mu=$ overall mean effect

$\mathrm{ti}=$ true effect of the $\mathrm{i}$

th treatment

eij $=$ error term of the jth unit receiving ith treatment

\section{Results and Discussion}

The observed overall mean value of Aspartate Aminotransferase (AST) (IU/L) in crossbred cows was $40.03 \pm 1.24$ which ranged from $33.11 \pm 0.47$ to $49.49 \pm 1.60$ during the peripartum period. Lowest value of AST was observed on the of day parturition as compared to any other peri-partum days. There were no any significant differences observed in AST levels during pre-partum period in the study. On the day of parturition the level of AST decreased significantly
$(\mathrm{P}<0.05)$ and after parturition from day 3 onwards the value started increasing significantly $(\mathrm{P}<0.05)$ reaching the highest value on day 45 of the peri-partum period. Results of present experiment were in consonance with observations of Nessim (2010) in Baladi cows, Liu et al., (2012) in Holstein cows and Yehia and Salem (2015) in dairy cows. However, Abdulkareem (2013) observed non- significant differences in AST levels in Iraqi riverine buffaloes around calving and postpartum period. While, Alameen and Abdelatif (2012) reported that the AST level was significantly higher during late pregnancy in crossbred cows. AST activity was numerically higher during early post parturient periods as compared to activity observed at calving indicating that hepatic metabolism might be more stressed and tissue catabolism was more pronounced during this period. However, the observed enzyme activities were within the normal range, integrity and functionality of liver tissue was obviously maintained during these periods. A similar trend was observed by Reist et al., (2003) for Holstein dairy cows, where AST activity was lowest pre - partum and reached its peak during the first week post-partum.

The observed overall mean value of Alanine aminotransferase (ALT) (IU/L) in crossbred cows was $14.50 \pm 0.49$ which ranged from $12.39 \pm 0.27$ to $17.87 \pm 0.45$ during the peripartum period. Lowest value of ALT was observed on the day parturition as compared to any other peri-partum days. There were no any significant differences observed in the values of ALT levels during pre-partum period. After parturition the value of ALT started increasing significantly $(\mathrm{P}<0.05)$ from day 3 onwards reaching the highest value on day 45 of the peri-partum period. Results of present experiment were in consonance with observations of Liu et al., (2012) in Holstein cows and Yehia and Salem (2015) in dairy cows. However, Mohamed et al., (2015) 
observed non- significant difference in ALT levels in buffalo heifers during pre and postpartum period. While, Nessim (2010) in Baladi cows reported that the ALT level tended to decrease significantly during postpartum period. Determination of Alanine aminotransferase (ALT) activity plays an important role in the diagnosis of cows manifest controlled to excess fat mobilization in early lactation which causes liver function injury and lead to variation of activity (Kaneko, 2008).The observed peripartum increase in serum enzymes indicated increased hepatic effort during this period.

The observed overall mean value of Alkaline phosphatase (ALP) (IU/L) in crossbred cows was $22.03 \pm 1.59$ which ranged from $13.15 \pm 0.51$ to $39.47 \pm 3.87$ during the peripartum period. Highest value of ALP enzyme was observed on the day parturition as compared to any other peri-partum day. There was no any significant difference observed in ALP levels during pre-partum period. On the day of parturition the level of ALP was increased significantly $(\mathrm{P}<0.05)$ and after parturition the value started decreasing significantly $(\mathrm{P}<0.05)$ from day 3 onwards reaching the lowest value on day 45 . Results of present experiment were in consonance with observations of Liu et al., (2012) in Holstein cows. However, Mostafa et al., (2014) observed non- significant differences in ALP levels in crossbred cows during pre and postpartum period. While, Abdulkareem (2013) reported that the ALP level dramatically declined at calving in Iraqi riverine buffaloes. Serum ALP activity increases in cases of hepatitis, biliary disorders or during growth due to active bone metabolism. Sato et al., (2005) noted that the serum ALP activity was found to be higher in lactation periods in comparison with the dry period because the bone metabolism and liver functions are more active during lactation period.
The observed overall mean value of Acid phosphatase (ACP) (IU/L) in crossbred cows was $1.37 \pm 0.02$ which ranged from $1.26 \pm 0.01$ to $1.53 \pm 0.02$ during the peripartum period. Highest value of ACP was observed on day 45 as compared to any other peri-partum day. There was no any significant difference found in ACP levels during pre-partum period. The value of ACP started increasing significantly $(\mathrm{P}<0.0 .5)$ from 3 days before to the day of calving. After parturition the ACP level started decreasing significantly $(\mathrm{P}<0.05)$ from 3 to 7 days after calving. The ACP values started increasing significantly $(\mathrm{P}<0.05)$ from 10 to 45 days after calving. Information on Acid phosphatase related to our study were scantly. However, a report of Chaurasia et al., (2016) represented that the value of ACP was significantly $(\mathrm{P}<0.01)$ highest in repeat breeder followed by reduced in normal cyclic and lowest in anestrous condition in Murrah buffaloes. The result was also similar to Ganguly (2013) who reported that increase in Acid phosphate concentration decreases with increase in follicular size. It can be inferred that higher concentration of acid phosphatase increases follicular activity resulting in repeat breeding. On the contrary, Sharma et al., (1986) reported that mean values of ACP were significantly $(\mathrm{P}<0.01)$ higher in normal cyclic Kankrej heifers. Increased activity of ACP might be helpful in hydrolysing the organic phosphomonoesters and thus provide energy in the form of phosphates in normal cyclic animals. The observed overall mean value of cortisol $(\mu \mathrm{g} / \mathrm{dl})$ in crossbred cows was $25.63 \pm$ 0.75 which ranged from $20.98 \pm 0.72$ to 31.36 \pm 1.87 during the peripartum period. Highest level of cortisol was observed on the day of calving as compared to all other peri-partum days. The concentration of cortisol differed non-significantly upto 10 days before calving, than cortisol level started increasing significantly $(\mathrm{P}<0.05)$ reaching the highest level on the day of parturition (Table 1). 
Table.1 Mean $( \pm$ SEM) values of enzymes in crossbred cows $(n=6)$ during peripartum period

\begin{tabular}{|c|c|c|c|c|c|}
\hline Days & $\begin{array}{c}\text { ALT } \\
\text { (IU/L) }\end{array}$ & $\begin{array}{c}\text { AST } \\
\text { (IU/L) }\end{array}$ & $\begin{array}{c}\text { ALP } \\
\text { (IU/L) }\end{array}$ & $\begin{array}{c}\text { ACP } \\
\text { (IU/L) }\end{array}$ & $\begin{array}{c}\text { Cortisol } \\
(\mu \mathrm{d} / \mathrm{dl})\end{array}$ \\
\hline-45 & $13.90^{\mathrm{cde}} \pm 0.54$ & $37.75^{\mathrm{de}} \pm 1.68$ & $23.07^{\mathrm{bcde}} \pm 4.20$ & $1.26^{\mathrm{d}} \pm 0.01$ & $20.98^{\mathrm{g}} \pm 0.72$ \\
\hline-38 & $13.05^{\mathrm{e}} \pm 0.44$ & $35.36^{\mathrm{ef}} \pm 0.35$ & $18.24^{\mathrm{e}} \pm 1.76$ & $1.29^{\mathrm{cd}} \pm 0.02$ & $22.39^{\mathrm{fg}} \pm 0.37$ \\
\hline-31 & $13.02^{\mathrm{e}} \pm 0.33$ & $37.95^{\mathrm{de}} \pm 1.70$ & $18.61^{\mathrm{de}} \pm 1.41$ & $1.34^{\mathrm{c}} \pm 0.02$ & $23.04^{\text {efg }} \pm 0.56$ \\
\hline-24 & $13.28^{\mathrm{de}} \pm 0.17$ & $38.85^{\mathrm{cde}} \pm 1.94$ & $19.60^{\text {cde }} \pm 1.66$ & $1.28^{\mathrm{cd}} \pm 0.02$ & $23.24^{\mathrm{efg}} \pm 1.2$ \\
\hline-17 & $13.51^{\mathrm{de}} \pm 0.47$ & $36.71^{\mathrm{def}} \pm 1.07$ & $18.79^{\mathrm{de}} \pm 1.45$ & $1.34^{\mathrm{c}} \pm 0.02$ & $24.46^{\mathrm{def}} \pm 0.85$ \\
\hline-10 & $12.93^{\mathrm{e}} \pm 0.45$ & $38.04^{\mathrm{de}} \pm 1.58$ & $22.16^{\mathrm{bcde}} \pm 1.49$ & $1.30^{\mathrm{cd}} \pm 0.04$ & $25.16^{\mathrm{de}} \pm 0.85$ \\
\hline-3 & $12.97^{\mathrm{e}} \pm 0.36$ & $38.24^{\mathrm{de}} \pm 0.94$ & $23.60^{\text {bcd }} \pm 1.53$ & $1.44^{\mathrm{b}} \pm 0.06$ & $26.18^{\mathrm{cd}} \pm 1.09$ \\
\hline $\mathbf{0}$ & $12.39^{\mathrm{e}} \pm 0.27$ & $33.11^{\mathrm{f}} \pm 0.47$ & $39.47^{\mathrm{a}} \pm 3.87$ & $1.48^{\mathrm{ab}} \pm 0.05$ & $31.36^{\mathrm{a}} \pm 1.87$ \\
\hline+3 & $14.80^{\mathrm{cd}} \pm 0.59$ & $38.50^{\mathrm{de}} \pm 0.67$ & $25.34^{\mathrm{b}} \pm 2.21$ & $1.32^{\mathrm{cd}} \pm 0.02$ & $29.82^{\mathrm{ab}} \pm 2.10$ \\
\hline+7 & $15.25^{b c} \pm 0.52$ & $40.52^{\mathrm{cd}} \pm 0.81$ & $21.60^{\mathrm{bcde}} \pm 1.43$ & $1.28^{\mathrm{cd}} \pm 0.03$ & $27.85^{b c} \pm 2.07$ \\
\hline+10 & $15.18^{c} \pm 0.47$ & $42.83^{b c} \pm 1.59$ & $24.63^{b c} \pm 3.52$ & $1.35^{\mathrm{c}} \pm 0.04$ & $26.65^{\mathrm{cd}} \pm 1.57$ \\
\hline+15 & $16.84^{\mathrm{ab}} \pm 0.61$ & $45.61^{\mathrm{ab}} \pm 1.29$ & $21.95^{\text {bcde }} \pm 2.38$ & $1.45^{\mathrm{ab}} \pm 0.02$ & $26.09^{\mathrm{cd}} \pm 1.65$ \\
\hline+30 & $17.45^{\mathrm{a}} \pm 0.56$ & $47.35^{\mathrm{a}} \pm 1.59$ & $18.14^{\mathrm{e}} \pm 2.00$ & $1.48^{\mathrm{ab}} \pm 0.02$ & $26.18^{\mathrm{cd}} \pm 1.55$ \\
\hline+45 & $17.87^{\mathrm{a}} \pm 0.45$ & $49.49^{a} \pm 1.60$ & $13.15^{f} \pm 0.51$ & $1.53^{\mathrm{a}} \pm 0.02$ & $26.23^{\mathrm{cd}} \pm 1.54$ \\
\hline GM & $14.50 \pm 0.49$ & $40.02 \pm 1.24$ & $22.03 \pm 1.59$ & $1.37 \pm 0.02$ & $25.63 \pm 0.75$ \\
\hline CD & 1.31 & 3.76 & 6.59 & 0.094 & 3.94 \\
\hline CV \% & 7.87 & 8.16 & 23.02 & 5.92 & 13.32 \\
\hline
\end{tabular}

Values having different superscripts differed significantly $(\mathrm{P}<0.05)$ within column

Table.2 Mean ( \pm SEM) values of antioxidant enzymes in crossbred cows $(n=6)$ during peripartum period

\begin{tabular}{|c|c|c|c|}
\hline Days & GPX $(\mathbf{n m o l} / \mathbf{m i n} / \mathbf{m l})$ & LPO $(\mathbf{n m o l} / \mathbf{m i n} / \mathbf{m l})$ & SOD $(\mathbf{U} / \mathbf{m l})$ \\
\hline $\mathbf{- 4 5}$ & $2.15^{\mathrm{e}} \pm 0.04$ & $2.82^{\mathrm{gh}} \pm 0.30$ & $51.84^{\mathrm{e}} \pm 0.47$ \\
\hline $\mathbf{- 3 8}$ & $2.25^{\mathrm{de}} \pm 0.02$ & $3.19^{\text {fg }} \pm 0.43$ & $51.61^{\mathrm{e}} \pm 0.46$ \\
\hline $\mathbf{- 3 1}$ & $2.44^{\mathrm{bcde}} \pm 0.02$ & $3.28^{\mathrm{efg}} \pm 0.16$ & $53.67^{\mathrm{de}} \pm 0.52$ \\
\hline $\mathbf{- 2 4}$ & $2.56^{\mathrm{bcd}} \pm 0.01$ & $4.00^{\mathrm{bcde}} \pm 0.76$ & $55.24^{\mathrm{cd}} \pm 0.28$ \\
\hline $\mathbf{- 1 7}$ & $2.60^{\mathrm{bcd}} \pm 0.02$ & $4.04^{\mathrm{bcd}} \pm 0.65$ & $55.42^{\mathrm{cd}} \pm 0.25$ \\
\hline $\mathbf{- 1 0}$ & $2.66^{\mathrm{bc}} \pm 0.01$ & $3.75^{\text {cdef }} \pm 0.34$ & $56.55^{\mathrm{cd}} \pm 0.19$ \\
\hline $\mathbf{- 3}$ & $2.66^{\mathrm{bc}} \pm 0.03$ & $4.24^{\mathrm{bc}} \pm 0.30$ & $57.50^{\mathrm{c}} \pm 0.25$ \\
\hline $\mathbf{0}$ & $3.57^{\mathrm{a}} \pm 0.02$ & $5.93^{\mathrm{a}} \pm 0.24$ & $62.33^{\mathrm{a}} \pm 0.20$ \\
\hline $\mathbf{+ 3}$ & $3.43^{\mathrm{a}} \pm 0.01$ & $4.50^{\mathrm{b}} \pm 0.40$ & $62.73^{\mathrm{a}} \pm 0.15$ \\
\hline $\mathbf{+ 7}$ & $3.24^{\mathrm{a}} \pm 0.02$ & $4.06^{\mathrm{bcd}} \pm 0.28$ & $63.40^{\mathrm{a}} \pm 0.12$ \\
\hline $\mathbf{+ 1 0}$ & $3.35^{\mathrm{a}} \pm 0.01$ & $2.96^{\mathrm{gh}} \pm 0.34$ & $61.75^{\mathrm{ab}} \pm 0.45$ \\
\hline $\mathbf{+ 1 5}$ & $3.24^{\mathrm{a}} \pm 0.02$ & $2.50^{\mathrm{h}} \pm 0.30$ & $61.40^{\mathrm{ab}} \pm 0.22$ \\
\hline $\mathbf{+ 3 0}$ & $3.17^{\mathrm{a}} \pm 0.01$ & $3.40^{\mathrm{defg}} \pm 0.34$ & $58.41^{\mathrm{bc}} \pm 0.34$ \\
\hline $\mathbf{+ 4 5}$ & $3.29^{\mathrm{a}} \pm 0.01$ & $3.98^{\mathrm{bcde}} \pm 0.27$ & $56.90^{\mathrm{cd}} \pm 0.10$ \\
\hline $\mathbf{G M}$ & $2.90 \pm 0.47$ & $3.76 \pm 0.22$ & $57.77 \pm 4.02$ \\
\hline $\mathbf{C D}$ & 0.059 & 1.12 & 0.90 \\
\hline $\mathbf{C V} \boldsymbol{\%}$ & 1.77 & 25.97 & 1.36 \\
\hline
\end{tabular}

Values having different superscripts differed significantly $(\mathrm{P}<0.05)$ within column 
After parturition from day 3 to day 10 the level of cortisol started decreasing significantly $(\mathrm{P}<0.05)$. The decrease in the cortisol level was non-significant from day 10 to day 45 . Results of present experiment were in consonance with observations of Ghanem et al., (2012) in Friesian cows, Teama and Gad (2014) in crossbred cows and Ashmawy (2015) in buffaloes and cows. Cortisol also, induced gluconeogenesis that provide adequate glucose supplement necessary for the fetal nutrition (Bell, 1995). The hormone pattern established during the latter portion of gestation triggers parturition. During the last three weeks of gestation, the fetus begins to release hormones from the adrenal cortex (predominantly cortisol). Cortisol from the fetus stimulates estrogen production by the placenta (Rhodes, 2003). Disturbed rest and uncomfortable resting areas during transition may result in a physiological stress response indicated by altered levels of plasma cortisol and increased heart rate in dairy cattle (Ladewig and Smidt, 1989).

The observed overall mean value of Glutathione peroxidase (GPX) $(\mathrm{nmol} / \mathrm{min} / \mathrm{ml})$ in crossbred cows was $2.91 \pm 0.48$ which ranged from $2.15 \pm 0.04$ to $3.57 \pm 0.02$ during the peripartum period. Highest value of GPX was observed on the day of parturition as compared to any other peri-partum day. The GPX level started increasing non-significantly from 45 day before calving. But on the day of parturition the GPX level was significantly $(\mathrm{P}<0.05)$ higher than any other day of the peri-partum period. After parturition the variations in concentration of GPX were observed to be non-significant from day 3 onwards to day 45 . The results of the present experiment were in consonance with the observation of Pilarczyk et al., (2012) in HF cows and Gong and Xiao (2015) in HF cows. Whereas, Sharma et al., (2011) reported that the GPX value was significantly lower in early lactating cows as compared to advanced pregnant cows. While, Konvicna et al., (2015) reported that a significant $(\mathrm{P}<0.05)$ decrease in GPX activity was recorded one week after calving as compared to the weeks 6 and 9 after calving. Glutathione peroxidase is selenium dependent enzyme and it has also antioxidant property. Plasma glutathione peroxidase is considered as an indicator of oxidative stress (Tüzün et al., 2002; Sharma et al., 2011). In present study GPX activity was found to be increased in cows towards parturition indicating more oxidative stress at the time of parturition (Table 2).

The observed overall mean value of Lipid peroxidase (LPO) $(\mathrm{nmol} / \mathrm{min} / \mathrm{ml})$ in crossbred cows was $3.76 \pm 0.22$ which ranged from 2.15 \pm 0.04 to $3.57 \pm 0.02$ during the peripartum period. Highest value of LPO was observed on the day of parturition as compared to any other peri-partum day. The LPO level started increasing non-significantly from 45 days before calving. But on the day of parturition the LPO level was significantly $(\mathrm{P}<0.05)$ higher than any other days of the peri-partum period. The value of LPO started decreasing significantly $(\mathrm{P}<0.05)$ from day 3 onwards to day 15. The value of LPO was increased significantly $(\mathrm{P}<0.05)$ from day 30 to day 45 . The results of the present experiment were in consonance with the observation of Sharma $e t$ al., (2011) in Holstein X Sahiwal crossbred dairy cows. Singh et al., (2014) reported high lipid peroxidation in fresh cows (3-30 days in milk). Castillo et al., (2005) and Castillo et al., (2006) showed a increased level of LPO around parturition and early lactation in dairy cows. Gong and Xiao (2015) also reported significantly $(\mathrm{P}<0.05)$ increased level of melondialdehyde in early lactation as compared to dry period and peak lactation. Whereas, Adela et al., (2008) reported that in the second week after parturition the level of melondialdehyde decreased significantly, and remained approximately at same levels during the experiment. Lipid peroxidation is one of 
the important consequences of oxidative stress (Kumaraguruparan et al., 2002). MDA is generated as a consequence of lipid peroxidation and, as such, is assayed as a biomarker of oxidative stress. Metabolic demand associated with the initiation of lactation would be expected to increase the production of ROS. Lipid peroxidation occurs when ROS react with polyunsaturated fatty acids. Peroxidation of lipids within cellular membranes can lead to changes in fluidity. This may explain why the highest serum MDA or LPO level was observed in earlylactation cows. In addition, lower antioxidant potential as a consequence of lactation stage can result in excess accumulation of ROS, which can induce lipid peroxidation.

The observed overall mean value of superoxide dismutase (SOD) (U/ml) in crossbred cows was $57.77 \pm 4.03$ which ranged from $51.61 \pm 0.46$ to $63.40 \pm 0.12$ during the peripartum period. Highest value of SOD was observed on the day 7 as compared to any other peri-partum days. The SOD level started increasing non-significantly from -30 day of the peri-partum period. But on the day of parturition the SOD level was significantly $(\mathrm{P}<0.05)$ higher as compared to any other pre-partum days. The value of SOD was higher on day 7 as compared to the day of parturition. The value of SOD was decreased non-significantly from day 10 to day 45 . The result of the present study was similar with the results obtained by Chandra and Agrawal (2009) in crossbred cows where they found that SOD activity increased upto calving and then decreased. Maurya et al., (2014) also found that the SOD value remained low at 60 days before calving and it is found to be increased on the day of parturition and after that the level start decreasing, Sheikh et al., (2015) also reported similar type of result in Sahiwal and Karan Fries cows. While Singh et al., (2014) reported that Superoxide dismutase levels were higher in pregnant cows than heifers. Whereas, Konvicna et al., (2015) reported in his study that the SOD activities were found to increase during whole monitored time i.e. from 3 weeks before parturition to 9 weeks after parturition in dairy cows. Adela et al., (2008) found that the SOD activity increases with passing days after parturition upto 6 weeks. The higher erythrocyte SOD activity on the day of parturition indicates higher oxidative stress and lower antioxidant status (Bernabucci et al., 2005). During our experiment, the SOD activities were gradually elevated, which was probably caused by a response of the organism to higher superoxide generation, especially after calving. Although the SOD activity increases after calving in dairy cows (Gaál et al., 2006), several recent studies have shown that the antioxidant capacity in periparturient dairy cows is insufficient to counteract the increase in ROS supply (Bernabucci et al., 2005; Castillo et al., 2005).

Serum concentration of ALT (U/L) and AST $(\mathrm{U} / \mathrm{L})$ were significantly $(\mathrm{P}<0.05)$ lower on the day parturition than any other days of the peri-partum period. While ALP (IU/L) and ACP (IU/L) levels were significantly (P < 0.05 ) higher on the day of parturition as compared to any other days of the peri-partum period. Concentration of hormone cortisol was significantly $(\mathrm{P}<0.05)$ higher on the day parturition than any other days during the peri-partum period. Antioxidant enzymes like SOD (U/ml), LPO (nmol) and GPx $(\mathrm{nmol} / \mathrm{min} / \mathrm{ml})$ were significantly $(\mathrm{P}<0.05)$ elevated on the day of parturition than any other days of the peri-partum period. The values of biochemical parameters including enzymes (AST, ALT, AKP and ACP) were influenced significantly $(\mathrm{P}<0.05)$ by the physiological changes occurring during the peri-partum period in the crossbred cows. Activity of antioxidant enzymes (LPO, SOD, GPx) were significantly increased during 
calving and also after parturition to encounter the parturition stress and post-parturient stress in animals.

\section{References}

Abdulkareem, T. A. (2013). Some hematological and blood biochemical attributes of Iraqi riverine buffaloes (Bubalus bubalis) around calving and postpartum periods. Al-Anbar Journal of Veterinary Sciences, 6(1):143-150.

Adela, P., Zinveliu, D., Pop, R. A., Andrei, S., and Kiss, E. (2008). Antioxidant status in dairy cows during lactation. Buletin USAMV-CN, 63: 130-135.

Alameen, A. O., and Abdelatif, A. M. (2012). Metabolic and endocrine responses of crossbred dairy cows in relation to pregnancy and season under tropical conditions. American-Eurasian Journal of Agricultural and Environmental Science, 12(8): 1065-1074.

Ashmawy, N. A. (2015). Changes in peripheral plasma hormone concentrations and metabolites during the last trimester of pregnancy and around parturition in the Egyptian buffalo and Baladi cows. Int. J. Adv. Res, 3(11):1377-1390.

Bell, A. W. (1995). Regulation of organic nutrient metabolism during transition from late pregnancy to early lactation. Journal of animal science, 73(9): 28042819.

Castillo, C., Hernandez, J., Bravo, A., LopezAlonso, M., Pereira, V., and Benedito, J. L. (2005). Oxidative status during late pregnancy and early lactation in dairy cows. The Veterinary Journal, 169(2): 286-292.

Castillo, C., Hernandez, J., Valverde, I., Pereira, V., Sotillo, J., Alonso, M. L., and Benedito, J. L. (2006). Plasma malonaldehyde (MDA) and total antioxidant status (TAS) during lactation in dairy cows. Research in Veterinary Science, 80(2): 133-139.

Chandra, G. and Agarwal, A., (2009) Effect of DL-a-Tocopherol acetate on calving induced oxidative stress in periparturient crossbred cows during summer and winter seasons. Indian Journal of Animal Nutrition, 26: 204210.

Chaurasia, R., Kushwaha, H. S., Chaurasia, D., Gendley, M. K., Kumari, K., Santra, A. K., and Shinha, B. (2016). Comparative studies of certain enzyme assay during various reproductive states in buffaloes. Buffalo Bulletin, 35(1): 33-38.

Gaal, T., Ribiczeyne-Szabo, P., Stadler, K., Jakus, J., Reiczigel, J., Kover, P., and Sumeghy, L. (2006). Free radicals, lipid peroxidation and the antioxidant system in the blood of cows and newborn calves around calving. Comparative Biochemistry and Physiology Part B: Biochemistry and Molecular Biology, 143(4): 391-396.

Ganguly S. 2013. Role of Biochemical factors and mineral supplementation in livestock ration for maintenance of their fertility and healthy reproductive status. Res. J. Chem. Sci., 3(6): 102-106.

Ghanem, M. M., Mahmoud, M. E., Abd ElRaof, Y. M., and El-Attar, H. M. (2012). Metabolic profile test for monitoring the clinical, haematological and biochemical alterations in cattle during peri-parturient period. Banha Veterinary Medical Journal, 23: 13-23.

Gitto, E., Reiter, R. J., Karbownik, M., Tan, D. X., Gitto, P., Barberi, S., and Barberi, I. (2002). Causes of oxidative stress in the pre-and perinatal period. Neonatology, 81(3): 146-157.

Gong, J., and Xiao, M. (2015). Selenium and antioxidant status in dairy cows at different stages of lactation. Biological trace element research, 171(1): 89-93. 
Hayirli, A., Grummer, R. R., Nordheim, E. V., and Crump, P. M. (2003). Models for predicting dry matter intake of Holsteins during the prefresh transition period. Journal of Dairy Science, 86(5): 1771-1779.

Ingvartsen, K. L., and Andersen, J. B. (2000). Integration of metabolism and intake regulation: a review focusing on periparturient animals. Journal of dairy science, 83(7): 1573-1597.

Kaneko, J. J., Harvey, J. W., and Bruss, M. L. (Eds.). (2008). Clinical biochemistry of domestic animals. Academic press.

Konvicna, J., Vargova, M., Paulíkova, I., Kovac, G., and Kostecka, Z. (2015). Oxidative stress and antioxidant status in dairy cows during prepartal and postpartal periods. Acta Veterinaria Brno, 84(2): 133-140.

Kumaraguruparan, R., Subapriya, R., Kabalimoorthy, J., and Nagini, S. (2002). Antioxidant profile in the circulation of patients with fibroadenoma and adenocarcinoma of the breast. Clinical Biochemistry, 35(4): 275-279.

Ladewig, J., and Smidt, D. (1989). Behavior, episodic secretion of cortisol, and adrenocortical reactivity in bulls subjected to tethering. Hormones and behavior, 23(3): 344-360.

Liu, P., He, B., Yang, X., Hou, X., Zhao, H., Han, Y., and Cheng, L. (2012). Activities of aspartate aminotransferase, alanine aminotransferase, gammaglutamyltransferase, alkaline phosphatase in plasma of postpartum Holstein cows. Journal of Animal and Veterinary Advances, 11(8): 12701274.

Maurya, P. K., Aggarwal, A., Singh, S. V., Chandra, G., Singh, A. K., and Chaudhari, B. K. (2014). Effect of vitamin $\mathrm{E}$ and zinc on cellular antioxidant enzymes in karan fries cows during transition period. Indian Journal of Animal Research, 48(2): 109-119.

Mohamed, G. A., Abd-Elnaser, E. M., and Elsayed, H. K. (2015) Preliminary Study on Lipid Profile with Relation to Total Antioxidant Capacity and some Hematological and Biochemical changes of Pre-Post-Partym Buffalo Heifers at Assiut City. Assiut Vet. Med. J. 61(144):159-165.

Mostafa, T. H., Elsayed, F. A., Ahmed, M. A., and Elkholany, M. A. (2014). Effect of using some feed additives (twprobiotics) in dairy cow rations on production and reproductive performance. Egyptian J. Anim. Prod, 51(1): 1-11.

National Research Council. (2001). Nutrient requirements of dairy cattle. National Academies Press.

Nessim, M. Z. (2010). Role of Some Hormones and Blood Components during Pregnancy and Post-Partum Periods in Baladi Cows. Journal of Radiation Research and Applied Sciences, 3(4B): 1319-1334.

Pilarczyk, B., Jankowiak, D., TomzaMarciniak, A., Pilarczyk, R., Sablik, P., Drozd, R., and Skólmowska, M. (2012). Selenium concentration and glutathione peroxidase (GSH-Px) activity in serum of cows at different stages of lactation. Biological trace element research, 147(1-3): 91-96.

Reist, M., Erdin, D. K., von Euw, D., Tschümperlin, K. M., Leuenberger, H., Hammon, H. M., and Blum, J. W. (2003). Postpartum reproductive function: association with energy, metabolic and endocrine status in high yielding dairy cows. Theriogenology, 59(8): 1707-1723.

Rhodes, R. C. (2003): The physiology of gestation of parturition. University of Rhode Island, in cooperation with the U.S. department of Agriculture 
Extension Service, West Virginia University.

Roche, J. F., Mackey, D., and Diskin, M. D. (2009). Reproductive management of postpartum cows. Animal Reproduction Science, 60: 703-712.

Rukkwamsuk, T., Geelen, M. J. H., Kruip, T. A. M., and Wensing, T. (2000). Interrelation of Fatty Acid Composition in Adipose Tissue, Serum, and Liver of Dairy Cows during the Development of Fatty Liver Postpartum1. Journal of Dairy Science, 83(1): 52-59.

Sato, J., Kanat, M., Yasuda, J., Sato, R., Okada, K., Seimiya, Y., and Naito, Y. (2005). Changes of serum alkaline phosphatase activity in dry and lactational cows. Journal of veterinary medical science, 67(8): 813-815.

Sharma, N., Singh, N. K., Singh, O. P., Pandey, V., and Verma, P. K. (2011). Oxidative stress and antioxidant status during transition period in dairy cows. Asian-Australasian Journal of Animal Sciences, 24(4): 479-484.

Sheikh, A. A., Aggarwal, A., Aarif, O., and Upadhyay, R. C. (2015). In vitro Effect of Zinc Treatment on the Antioxidant Status of Heat Stressed Peripheral Blood Mononuclear Cells of Periparturient Sahiwal and Karan Fries Cows-A Comparative Study. Journal of Animal Research, 5(2): 243.

Singh, G., Randhawa, S. N. S., Nayyar, S., Chand, N., and Randhawa, C. S. (2014). Evaluation of Oxidative Stress during
Periparturient Period in Crossbred cows. Intas Polivet, 15(2): 188-191.

Sordillo, L. M., O'boyle, N., Gandy, J. C., Corl, C. M., and Hamilton, E. (2007). Shifts in thioredoxin reductase activity and oxidant status in mononuclear cells obtained from transition dairy cattle. Journal of Dairy Science, 90(3): 11861192.

Teama, F. E. I., and Gad, A. E. (2014). Leptin, Thyroxin and Cortisol Hormones and Some Metabolic Products during Pre and Postpartum Periods in Cows in Relations to Their Body Weight of Newborn Calves. Global Veterinaria 12(1): 59-66.

Tuzun, A., Erdil, A., Inal, V., Aydin, A., Bağcı, S., Yeşilova, Z., and Dağalp, K. (2002). Oxidative stress and antioxidant capacity in patients with inflammatory bowel disease. Clinical biochemistry, 35(7): 569-572.

Wathes, D. C., Cheng, Z., Chowdhury, W., Fenwick, M. A., Fitzpatrick, R., Morris, D. G., and Murphy, J. J. (2009). Negative energy balance alters global gene expression and immune responses in the uterus of postpartum dairy cows. Physiological Genomics, 39(1): 1-13.

Yehia, S. G., and Salem, N. Y. (2015). Assessment of some biochemical parameters in dairy cows during transition period. International Journal of Veterinary Science, 4(4): 227-230.

\section{How to cite this article:}

Anju Yadav, M.M. Pathan, S.P. Madhira, A.M. Pande and Modi, R.J. 2019. Assessment of Biochemical and Antioxidant Enzymes and Stress Hormone in Crossbred-Cows during Peripartum Period. Int.J.Curr.Microbiol.App.Sci. 8(07): 1463-1472.

doi: https://doi.org/10.20546/ijcmas.2019.807.174 